Pobrane z czasopisma Annales I - Philosophy and Sociology http://philosophia.annales.umcs.pl Data: 26/04/2023 15:33:54

DOI: $10.17951 / i .2018 .43 .1 .97-110$

A N N A LES

UNIVERSITATIS MARIAE CURIE-SKŁODOWSKA

LUBLIN - POLONIA

VOL. XLIII, 1

SECTIO I

2018

\title{
ТЕТЯНА ЛАПАН
}

ORCID ID: https://orcid.org/0000-0002-3133-9707

Львівський національний університет імені Івана Франка

\section{Женщины в АТО: украинский опыт современной войны}

Kobiety w ATO: ukraińskie doświadczenie nowoczesnej wojny

Когда ты спишь всю ночь в берцах и думаешь, а вдруг это последняя, так что я могу сказать, что лучший учитель - это жизнь, ее уроки невозможно прогулять. Все можно приобрести, но в жизни невозможно прогулять уроки. И теперь как я здесь нахожусь, у меня флаг есть дома, висит в зале и я всегда на него смотрю и там есть такая фраза Воспоминания лучшие мои сокровища, их никто не может украсть. $[\ldots]$

Я сильная, я свободная, я упрямая, красивая, счастливая, откровенная Я солнце, я луна, я звезды, я река, я поле, я море Я капля, я наводнение, я ливень, я дочь, я мать, жена Я цветок, я ночное желание, я утро, твоя я любовь Я песня, страница романа, я первая такая и последняя ${ }^{1}$.

\section{ВСТУПЛЕНИЕ}

Женщины находятся в зоне боевых действий на Востоке Украины с начала ведения Антитерористичесской операции (далее: АТО). Именно поэтому был осуществлен проект «In Memory of Lesya Kyzyk Research Project in Oral History: Ukrainian Women in the Military Conflict in Eastern Ukraine (20142016)». Особенность проекта состояла в биографическом интервьюировании женщин - участниц современных боевых действий на Востоке Украины.

1 Архив устной женской истории при Лектории Союза Украинок Америки (далее: СУА) Украинского католического университета (УКУ): Людмила, 1979, Львовская область, Яворовский район, с. Молошковичи, военная. 
Pobrane z czasopisma Annales I - Philosophy and Sociology http://philosophia.annales.umcs.pl Data: 26/04/2023 15:33:54

Несколько десятков монографий и сотни научных статей, освещающих различные аспекты истории женщин со времен казачества до постсоветских трансформаций, является показателем стремительного развития этого исследовательского направления в украинской исторической науке2 участия женщин в военных действиях является актуальной в гендерных усноисторических студиях. Однако научных публикаций, в которых бы освещался вопрос участия женщин в современных военных действиях в Украине недостаточно. Статья посвящена результатам проекта, который развивает концепцию женских усноистоических студий на современном украинском материале. Архив проекта становит 42 биографических интервью с женщинами, имеющими опыт пребывания в зоне АТО, которые родились между 1960 и 1990 годами и проживают сейчас на всей территории Украины (кроме оккупированного Крыма и Донбасса). Все интервью происходили на мирной территории Украины, после возвращения женщин из АТО. Опрос охватил значительную часть регионов страны, а именно Львовскую, Киевскую, Черниговскую, Харьковскую, Херсонскую, Днепропетровскую, Хмельницкую, Полтавскую области. С начала интервьюирования было оговорено, что женщины не описывали мест дислокации частей на передовой, в которых находились.

Проведенные полуструктурированные биографические интервью, состояли из тематических блоков и содержали перечень обязательных направлений, по которым необходимо было получить информацию от респондента. Использовав биографическое интервьюирование мы получили возможность проанализировать путь женщины в дихотомическом связи мира и войны; войны и возвращения к мирной жизни. Тематические блоки соответствуют последовательности жизненных циклов индивида: детство; юность; профессиональная деятельность в мирное время; семья; события Революции

2 О. Кісь, Українки в ГУЛАГУ: вижити значить перемогти, Львів 2017; Жінки Центральної та Східної Європи у Другій світовій війні: Гендерна специффіка досвіду в часи екстремального насильства, ред. Г. Грінченко, К. Кобченко, О. Кісь, Київ 2015; Н. Дейчаківська, Незвичайні долі звичайних жінок: Усна історія двадиятого століття, Львів 2013; Г. Грінченко, Усна історія примусу до прачі: метод, контексти, тексти, Харків 2012; Л. Буряк, Жінка в українському історичному наративі: автори, ідеї, образи (друга половина ХІХ - перша третина XX cm.), Київ 2010; В. Суковата, Гендерна ідентичність і конструювання пам'яті кризових моментів історії: жіночі стратегії виживання, «Соціологія: теорія, методи, маркетинг» 2009, № 2, с. 67-95; О. Кісь, Жіночий досвід участі у національно-визвольних змаганнях на західноукраїнських землях у 1940-50-х роках, [в:] Схід/Захід. Історико-культурологічний збірник, Вип. 13-14: Історична пам'ять і тоталітаризм: досвід Центрально-Східної Європи, Харків 2009, с. 101-125; Т. Лапан, Украӥнські жінки на примусових роботах у Третьому Райху, «Україна модерна» 2007, Число 11, с. 127-139. 
Pobrane z czasopisma Annales I - Philosophy and Sociology http://philosophia.annales.umcs.pl Data: 26/04/2023 15:33:54

Достоинства; война; причины, мотивация участия респондента в военных событиях; пребывания на линии ведения боевых действий; военная повседневность; возвращение из АТО; адаптация к условиям мирной жизни; личный анализ военных событий. Именно то, на чем акцентируют женщины свои воспоминания, как они интерпретируют те или иные социальные и личные довоенные - военные - послевоенные события, реконструируют свой жизненный путь, и стало целью нашего исследования. Биографическое интервью позволило осуществить, в первую очередь, самоанализ для респондента; саморефлексию, которая включала размышления над своими действиями, поступками; самопрезентацию женщиной себя в рассказе. Проанализировать значимые для женщин события и состояния и стало целью проекта, которые мы бы хотели впервые предоставить как первоначальные выводы в данной статье.

С биографией следует связывать неограниченные потенции уникального и индивидуального в «жизненном мире» человека. Феномен биографии может быть раскрыт в единстве жизни и текста, экзистенциального и нарративного измерений. Такая двойственность требует использования различных гуманитарных дисциплин - социологии, истории, психологии, культурной и социальной антропологии, лингвистики, семиотики и др., синтеза их специфических методов и приемов. Многозначность, богатство смыслов языка «историй жизни» нуждается в анализе и дешифровке со стороны различных дисциплин.

Авторитетным началом биографического метода в социологии считают пятитомное издание В. Томаса и Ф. Знанецкого Польский крестьянин в Евpone и Америке ${ }^{3}$. Идеи известного польского философа и социолога Ф. Знанецкого по эффективности использования метода анализа биографий как средства для получения валидных сведений о социальных изменениях, об особенностях формирования социальных групп и институтов достаточно широко обсуждались на протяжении всего XX в. Поворот к более интенсивному использованию биографических материалов наступает в нач. 70-80-х гг. $\mathrm{XX}$ в. ${ }^{4}$ В пределах гуманистической переориентации, возростает интерес к человеку как индивидуальности, его уникальному и неповторимому опыту переживаний, поэтому биографический метод широко используется и сейчас, в последнее десятилетие XXI в.

3 Л. Скокова, Флоріан Знанецький: автобіографічний метод у соиіології, «Соціологія: теорія, методи, маркетинг» 1998, № 6, с. 161.

4 Л.Г. Скокова, Біографічні дослідження в соиіології: традииія і сучасний досвід, Київ 2004, c. 16. 
Pobrane z czasopisma Annales I - Philosophy and Sociology http://philosophia.annales.umcs.pl Data: 26/04/2023 15:33:54

Сегодня же исследователи отмечают, что существуют различия между мужскими и женскими биографическими воспоминаниями. Ученые немало внимания уделяют тому, что именно и как запоминают женщины и мужчины в событиях, которые им пришлось одинаково пережить. Итак, актуальность темы заключается в том, чтобы задокументировать биографические свидетельства женщин, которые стали очевидцами вооруженного конфликта на Востоке Украины. «Биографическая память»- это субъективное отражение пройденного человеком отрезка жизненного пути, который отличается фиксацией, хранением, интерпретацией и актуализацией биографически значимых событий и состояний5. Первоочередным заданием проекта является именно женское восприятия предвоенных - военных - послевоенных событий в Украине.

На протяжении 2016 в Украине был совершен также другой проект «Невидимый батальон». Проект выполнялся благодаря информационной и финансовой поддержке МБФ «Украинский женский фонд». Основной акцент этого проекта сделан на профессионализацию украинской армии. Женщины в армии могли быть поварами, прачками, кочегарами, но не снайперами, не занимать руководящие военные должности. Цель проекта «Невидимый батальон» - изменить гендерные стереотипы в обществе, чтобы облегчить женщинам самореализацию в силовых структурах ${ }^{6}$. Проведение проектов свидетельствует о важности проблематики участия женщин в военных действиях на Востоке страны.

Одна из основных задач проекта «In Memory of Lesya Kyzyk Research Project in Oral History: Ukrainian Women in the Military Conflict in Eastern Ukraine» состояла в том, чтобы показать, какое значительное количество женщин, включено в события войны на Востоке Украины. Уже сегодня можно выделить несколько этапов военных действий. Так, в первую очередь, можно утверждать о начальном добровольческом периоде, где женщины участвовали наряду с мужчинами в обороне своей страны. Сегодня ситуация в АТО, очевидно, несколько иная, чем в течение 2014-2016 гг. А потому, происходят изменения как в количественном, так и в качественном составе групп женщин, участвующих в военных действиях. Количество женщин-военнослужащих в Украине неуклонно растет. В 2016 г., согласно статистике Министерства обороны, в Вооруженных Силах Украины проходят военную службу и работают 49552 женщины. Среди них

5 Суспільні злами і поворотні моменти: макроподії крізь призму автобіографічної розповіді, ред. О.Р. Кісь, Г.Г. Грінченко, Т. Пастушенко, Львів 2014, с. 18.

6 Невидимий Батальйон (фільм), https://uk.wikipedia.org/wiki_Невидимий_Батальйон_(фільм) [доступ: 10.10.2018]. 
Pobrane z czasopisma Annales I - Philosophy and Sociology http://philosophia.annales.umcs.pl Data: 26/04/2023 15:33:54

17147 военнослужащих-женщин $(8,5 \%$ от общей численности военнослужащих), в том числе 2540 офицеров (5,3\%), 14607 солдат и сержантов $(9,4 \%)$ и 32405 гражданского персонала. Только с начала 2016 г. на рядах армии количество военнослужащих-женщин увеличилась на $5,8 \%$ от общего количества принятых, из них 55 человек были приняты на офицерские должности. Более 2000 женщин признаны участниками боевых действий7. Это статистика без учета бойцов добровольческих батальонов. Министр обороны Украины С. Полторак заявил, что участниками антитеррористической операции на востоке Украины стали около 6000 женщин-военнослужащих ${ }^{8}$. В 2017 г. в АТО зафиксировано более 20000 женщин ${ }^{9}$. Такие разные количественные данные еще раз свидетельствуют о не ведущейся надлежащим образом военной статистике. А о количестве женщин в добровольческих отрядах данные вообще отсутствуют.

Первоочередная задача проекта состояла в том, чтобы указать на широкий круг женщин-участников антитеррористической операции. В зоне АТО находятся не только женщины-военные или женщины-военные медики. Значительной является группа опрошенных женщин-добробаток, а наибольшую часть опрошенных составляют волонтеры. Среди волонтеров выделим группу гражданских медиков, которые организовали Первую медицинскую роту, группу «Белые береты», группу «Т-Хелперов», госпитальеров. Группы женщин, которые были охвачены проектом, не являются постоянными. Происходит увеличение количества женщин-воинов контрактниц, и, наоборот, количество женщин-добровольцев и женщин-волонтеров в зоне АТО уменьшается. Это обусловлено целым рядом причин, среди которых, в первую очередь, отметим социально-экономическую ситуацию в стране, изменение материального обеспечения армии. Например, женщины-волонтеры, становятся медиками-инструкторами, так как на передовой нужен медицинский персонал. Женщины гражданские медики или женщины-добробаткы подписывают контракт с ВСУ, Национальной гвардией.

Среди опрошенных респонденток мы выделели две группы - женщины, имеющие военный опыт до событий начала войны, и женщины - гражданские, мирные лица, которые никогда не состояли на военной службе

7 Тепер жінки можуть займати більше посад в армії, www.mil.gov.ua/diyalnist/ genderni-pitannya-u-sferi-bezpeki/teper-zhinki-mozhut-zajmati-bilshe-posad-v-armii.html [доступ: 10.10 .2018$]$.

8 Через АТО пройшло шість тисяч жінок, www.ukrinform.ua/rubric-ato/2349421-cerezato-vze-projsli-sist-tisac-zinok.html [доступ: 10.10.2018].

9 Зараз в українській армії служать близько 20 тисяч жінок, https://ua.censor.net.ua/ n435740 [доступ: 10.10.2018]. 
Pobrane z czasopisma Annales I - Philosophy and Sociology http://philosophia.annales.umcs.pl Data: 26/04/2023 15:33:54

102

Тетяна Лапан

(условно, «те, кто взяли в руки оружие впервые» с началом войны в Украине). На основе проведенных интервью в первой группе мы выделили две подгруппы: женщин офицерского и неофицерского состава. Среди второй группы опрошенных большинство имеет высшее образование, несколько научный степень - кандидатов и докторов наук. Среди женщин-гражданских профессиональный состав разнородный: учителя, медики, частные предприниматели, психологи, программисты, медсестры, парикмахеры, студенты, которые с началом Революции Достоинства или уже с началом военных действий решили быть задействованными на Востоке Украины.

\section{ТЕМАТИКА РАССКАЗОВ}

Каждый из блоков биографического интервью интересен сам по себе. Очевидно, в рамках одной статьи невозможно охватить все актуально поднятые темы в интервью, поэтому мы избрали для анализа тему мотивации участия в АТО и военную повседневность.

Мотивация участия женщин в АТО чрезвычайно разная. Причины поездок в АТО вцелом можно разделить по следующим факторам: патриотически-идейные убеждения, личные (семейные, родственные), экономические, служебно-профессиональные. Разным и не всегда положительным является отношение ближайшего окружения (семья, друзья) до выезда женщин в ATO. Уже на этом этапе происходит определенное давление на женщину, чтобы отговорить ее от службы. Среди опрошенных в проекте есть несколько женщин, которые прошли уже не одну ротацию на Востоке.

Ну так как мне моя мама рассказывала, ты как ехала первый раз я боялась, а как второй раз я еще больше боялась. И дети так же, мамка вы уже были и зачем вы едете. Меньшая, я уже рассказывала, мама вы о нас не подумали на кого вы нас оставляете и не едьте, я без вас скучаю и без вас закончится, почему вы едете, мама вы не езжайте. Но я пообещала, если командир позвонит ехать, то я поеду, я пообещала. У меня муж говорит, что ты очень отдаешься армии, ты очень отдаешься работе, но у меня другого выхода нет, я уже была психологически настроена, поэтому когда я оттуда уезжала, что я вернусь назад, я пообещала вернуться и я знала, что как я отбуду дома, то я должна вернуться, так что я собрала вещи и вернулась назад, тяжело было, но знаешь что ты там нужна, что тебя там ждут. Мне еще повезло я знала, чтобы там не было или как там, что меня муж поддержит, он никогда там не упрекнет в чем, надо значит надо, такова моя судьба. Я сказала что я военная, я ничего изменить не могу если есть необходимость ехать я буду ехать, говорю ты взял женщину военную ${ }^{10}$.

10 СУА УКУ: Людмила, 1979, Львовская область, Яворовский район, с. Молошковичи, военная. 
Pobrane z czasopisma Annales I - Philosophy and Sociology http://philosophia.annales.umcs.pl Data: 26/04/2023 15:33:54

Женщины в АТО: украинский опыт современной войны

103

Акцент в интервью был сделан на женской повседневности на передовой. Интересными и которым женщины придают особого внимания оказались темы одежды, внешнего вида, литературной деятельности, особенностей питания, быта, досуга. Женщины рассказывают об изменениях в отношении к одежде (преимущество по выбору удобства и простоты), как правило, отсутствие макияжа, аксессуаров. Если одевают украшения, то оно маркировано украинской символикой. В части интервью нам удалось проследить попытки женщин сознательно подчеркнуть образ женственности, попытки показать себя как веселых, жизнерадостных, беззаботных женщин. Общение с мужчинами происходит в легкий, непринужденный, «игривый» способ. Эта часть женщин ухаживает за собой, насколько это возможно, в боевых условиях. Они чистоплотны, поддерживают чистоту и порядок с одеждой, укладывают волосы, делают макияж. В другой части интервью, женщины, наоборот, нивелируют свою женственность, они работают над внешним образом так, чтобы не отличаться от мужчины-военного. Они сознательно отвергают все феминные признаки. Эта часть женщин, предполагаем, в какойто мере словесно или физически подверглась насилию со стороны мужчин. Поэтому для упрощения отношений с мужчинами, женщина выбирает модель (хотя бы во внешнем виде) «уподобление мужчине-военному». Насилие (словесное, физическое) со стороны мужчин, в основном, происходит в состоянии алкогольного или наркотического опьянения.

Сталкиваясь с другими женщинами в боевых действиях, скажем так я не всегда была рада этой встрече, по одной простой причине, потому что, ну если бы это неприятно звучало, но некоторые женщины приехали туда действительно кого-то подцепить. Действительно приехали показать что-то, что не надо было показывать в этих условиях, потому что это другое. Я понимаю, что часто всех остальных так воспринимают сугубо через такую категорию женщин. Есть конечно мужчины, которые ведут себя супер по-хамски, ну типа они ведут себя так здесь и они себя ведут так там - ничего не поменялось, они какие были, такие и есть. Но через, ну я же говорю, некоторую категорию женщин, которые появляются, особенно если это женщины - кадровые военные, это страшно как для меня, честно было. С этим, я сталкивалась, это бы [...] ну вот есть женщины, которые пытаются быть на уровне с чуваками, ребята это плюс-минус ценят, нормально воспринимают. На уровне быть это не значит $[. .$.$] да, иногда надо что-то таскать, иногда надо что-то делать на уровне, но$ это не значит, что ты должна там позже где-то в отдельных промежутках надо подчеркнуто демонстрировать, что ты женщина. Я считаю, что на войне не приемлимы такие вещи ну как распущенные волосы, это блин, стадо голодных чуваков, это немножко не оно. Плюс там какие-то откровенно кстати сексуального характера, которые там ну да, всяких там ты можешь в балахоне быть, а ежели кому-то там что-то приснится - это его фантазия. Но если ты на реально откровенно - провоцируют. Да. есть футболка, да, есть декольте. И это разные вещи, и ты когда наклоняешься перед чуваком, то это блин, ты же понимаешь, что в любых условиях, в гражданских условиях - ты привлекаешь к себе внимание. Здесь внимание другое и это типа слегка ненормально. В связи с этим была лично у меня одна ситуация такая, 
Pobrane z czasopisma Annales I - Philosophy and Sociology http://philosophia.annales.umcs.pl Data: 26/04/2023 15:33:54

Тетяна Лапан

мы везли раненого, он был достаточно тяжелый и мы его уже стабилизировали нам недалеко его везти, но моя задача, чтобы он не терял сознание. Мы и пели и говорили и курили, кароче, мы делали все что хочешь, только не танцевали - ему было нельзя. И я говорю, ну что тебе еще сделать, у меня уже поток фантазии иссяк, все. Поговори со мной, скажи ну что ты хочешь. Он говорит, можно я тебя за сиську возьму. И бери хоть две, я все равно в бронике. Он так и ехал держа меня за то место, где теоретически должна быть грудь (смеется). И мы уже настолько уставшие были этим процессом, мне было все равно (смеется). Просто, ну как бы в нормальных условиях, я бы очень агрессивно на это все реагировала бы. А здесь, во-первых, мне надо, чтобы он «не уезжал», а во-вторых, ну я в бронежилете. Он говорит, Господи [...] ну ему типа казалось что все круто и мне казалось что все круто, потому что он тренда и рассказывает о чем-то и там вспоминает какие-то свои фантазии и типа Слава Богу, он доехал. Ну какие типа иногда такие ситуации бывают, или же там бывают иногда курьезы [...] ну без юмора, юмора там нельзя так крыша съедет просто. И юмор такой иногда довольно жесткий, но все привыкают и спокойно к этому относятся ${ }^{11}$.

Тема мародерства, коррупции, алкоголизма, наркомании и других девиаций в интервью раскрывается респондентами крайне редко и неохотно. Гендерное неравенство и насилие являются открытыми для обсуждения с женщинами-добровольцами, волонтерами, и наоборот, более закрытой для любых дискуссий с женщинами с ВСУ, Национальной гвардии. Женщины в АТО находятся в хорошей физической и профессиональной форме, а потому на передовой «ведут бой» за свой выход «с мужской тени». Соблюдение военной дисциплины, опрошенные женщины, в основном, возлагают на командиров частей. Отношение к женщинам в армии или добровольческих отрядах, в первую очередь, формируется на основе «позитивного или негативного» отношения к женщине в группе командирами. Кто является для них женщина-военная, та, которая выполняет свои профессиональные обязанности наравне с мужчинами-военными или некое «бремя» для группы, которой нельзя поручить выполнение боевых задач. То есть речь идет об уже сложившихся стереотипах в представлениях мужчин в отношении женщинвоенных. В первую очередь, от их отношения к участию женщин в войне зависит в дальнейшем формирование отношений офицерского и неофицерского состава группы. С другой стороны, опрошенные женщины отмечают, что больше мужского внимания они получают именно на передовой, а не в мирной жизни. В зависимости от того, какую модель поведения выбирает женщина в группе, таким и является к ней отношение. Если женщина видит себя в группе хозяйкой, то на нее ложатся соответствующие обязанности. Если женщина видит себя в роли снайпера, то она будет добиваться того, чтобы и другие члены группы признали ее профессиональные компетенции. «Уже через полгода с ними для одних я была как сестра, для одних как

11 СУА УКУ: Наталия, 1983, Черниговская область, г. Нежин, психолог. 
Pobrane z czasopisma Annales I - Philosophy and Sociology http://philosophia.annales.umcs.pl Data: 26/04/2023 15:33:54

Женщины в АТО: украинский опыт современной войны

мама, для старших была как дочь по-разному меня называли, кто Люда, кто Людмила, Людмила Ивановна, Ивановна [...]» ${ }^{12}$.

В части из опрошенных женщин на передовой появляется особый литературный талант, которого не было до пребывания в зоне АТО.

У меня в голове крутилось, куча крови, куча оружия, много смертей и я не знаю как получилось и так пошло, стих за стихом и так пошло, революционный настрой. [...] Ну знаете, должно быть какое-то вдохновение, то не так, что я там села, знаете как там такие поэты, я не знаю как они там делятся, я никогда не писала, у меня должен быть такой толчок и у меня все таки, как начался Майдан были такие революционные, такие настроение боевые, и здесь если мне что-то надо задуматься, такой поймать момент, такую тему поймать и тогда эта мысль начинает развиваться и тогда я передаю, я пишу. Потом я себе что-то корректирую и такое у меня что-то получается, не знаю кому там нравится или нет ${ }^{13}$.

Те женщины, которые никогда не писали ни прозаических, ни стихотворных произведений, начинают свое литературное творчество. В основном это патриотические и лирические произведения. Они охотно их цитируют во время интервью. Из воспоминания респонденты:

Потому что как начался Майдан я никогда изначально не писала стихов, а потом как начали к нам возить ребят мертвых у меня что-то такое призвание именно в себе проснулось и я начала писать стихи [...]. В 2014 г., когда начались бои у нас погиб первый мальчик с радиоцентра 22 года радиотелеграфист и наши потом приехали и рассказывали как начали обстреливать мы бежим в брониках и касках четверо падаем в окоп, а встаем трое в одной половине головы снесло прямо с каской и тогда я написала первое стихотворение «Ночь и сон» потом как начали ехать «двухсотые» я его посвятила всем и когда ты кого-то теряешь близкого, я написала такое стихотворение:

Качала мать сына в колыбельке своей, подрастал сынок красивый, как ангелочек золотой и война пришла нежданно и забрала всех сыновей.

Плачет матушка Украина ой не снилось таких снов.

Воевал сыночек долго и выполнял приказ, но пуля вражеская сердце поразила в один час.

В гробу сосновом черном сына матери дали мать плачет и рыдает сына своего прижимает прижимает и ласкает как птица свое дитя и открывает глаза снова, но сына уже нет. Ox, нету моего сына, мать снова заводит и заводит и рыдает ведь герои не умирают. Не умирает Украина не умрет, не умрет не одна жизнь сына еще пойдет за мир в стране.

12 СУА УКУ: Людмила, 1979, Львовская область, Яворовский район, с. Молошковичи, военная.

13 Ibidem. 
Pobrane z czasopisma Annales I - Philosophy and Sociology http://philosophia.annales.umcs.pl Data: 26/04/2023 15:33:54

Ложишься спать и не знаешь снова утром проснешься иль нет свою мамочку обнимаю и вспоминаю свою жизнь детство, школу и обучение, и юность, армию, семью и их не забываю, потому что очень сильно их люблю.

Далеко они от меня война подкралась издали, скажи как выдержать мне это расстояние как небытие... ${ }^{14}$

Мы спим - а у них тяжелый бой - нехватка патронов, отсутствие связи.

Ты говоришь: айфон недостаточно крутой,

А они всю ночь стреляют, мрази.

Ты жалуешься на недостаток внимания, А они молятся, чтобы выжить в бою.

У тебя проблема - с девченкой расставание, А им бы лишь еще раз увидеть семью.

Мы жалуемся на холод в квартире,

Когда они в окопе «трехсотого латают».

Ты говоришь про несправедливость в мире,

А они на глазах одного в бою теряют.

Ты в клуб на машине с сигаретой во рту,

А у них на ужин пара картошек на семерых.

Они под градами стоят всю ночь на блокпосту,

Мечтая о том, как когда-то обнимут родных.

Они знают, что не все вернутся, но живут надеждой и идеей борьбы.

Тебе на учебу лень проснуться.

Они там, чтоб ты здесь не знал войны.

Вернутся ли оттуда - знает только Бог.

Они стоят плечом к плечу на страже правды.

Для них не существует привычных нам тревог.

Теперь их кровью заново перепишут уставы.

Уважай, не позорь их шаг за шагом.

Им не нужны почести, звания героев.

Они там, что б ты не знал войны отравы,

Они там, что б ты мирно спал дома ${ }^{15}$.

Не менее интересны рассказы женщин о продовольственных, материальных проблемах на передовой. Никто из женщин не вспоминает о недоедании в АТО. Значительной была и есть помощь в этом вопросе волонтеров. Вспоминают однако о однообразном рационе пищи, который приводит к избыточному весу. Часто женщины-военные рассказывают о помощи волонтеров с женскими средствами гигиены, одеждой и другими материальными вещами нужными для них на передовой.

\footnotetext{
14 Ibidem

15 СУА УКУ: Ирина, 1993, г. Львов, военная.
} 


\section{Отметим также смену ценностей женщин на мирной территории и в АТО.}

И потом в последнюю неделю, когда я ездила на передовую удалось переночевать несколько ночей, командир говорит теперь ты можешь гордиться, что ты была на передовой, а там уже была такая тревога, что сепаратисты наблюдаются. И я говорю позвонила учительница первой дочери и говорит: «Ой вы знаете целый класс пошел с уроков и ваша дочь с ними, но я слышала, что вас нет, вы там». И когда ты там просто думаешь, а я хотела ей сказать, у нас ребята умирают с красными дипломами, а тут вы мне за какую-то безделушку звоните, потому что целый класс пошел и моя дочь ушла с урока, в этот момент уже не имеет значения никакого. Поэтому немножко начинаешь просматривать эти моменты по другому, вы ее не ругайте а так говорите, чтобы она оставалась. Во-первых, она не может остаться если целый класс пошел и, во вторых, такие мелочи там, они совсем не совместимы. Я сказала хорошо, спасибо. Я как приехала то дочь даже не ругала а спросила: Диана было такое, а она сказала: да, было. Просто ты там понимаешь какие это мелочи и как люди живут мелочами, есть моменты гораздо страшнее в жизни. Когда ты спишь всю ночь в берцах и думаешь, а вдруг это последняя, так что я могу сказать, что лучший учитель это жизнь, ее уроки невозможно прогулять. Все можно приобрести, а в жизни невозможно прогулять уроки. И теперь как я здесь нахожусь, у меня флаг есть дома, висит в зале и я всегда на него смотрю и там есть такая фраза «Воспоминания лучшие мои сокровища, их никто не может украсть». Ну я приехала и может теперь по другому немного смотрю я даже разучилась [...] одеваться и по характеру я очень правильная в жизни и то тяжело через себя, ты чемто проникаешься, и то тяжело переносить такие тяжелые моменты ибо всякое бывает, ты начинаешь переживать за каждого. И даже мои ребята говорили, что вас так надолго не хватит, если вы так все через себя будете пропускать через сердце, смотрите немножко по-другому. Оно так не получается, все же женщина, к кому больше привязываешься, кого больше жалеешь и когда что-то происходит, то трудно переживаешь ${ }^{16}$.

Важными на передовой становятся доверие, взаимопомощь, солидарность, слаженность группы. Поэтому женщины после возвращения постоянно проводят телефонные разговоры с теми, кто остался в АТО. Они постоянно пытаются быть «включенными» в жизни группы, где находились на службе или ездили как волонтеры. Происходит процесс «постоянной включенности» в военных действиях на мирной территории.

\section{Отдельно в интервью звучит тема налаживания контактов с местным} населением. Большинство опрошенных отметили недоверчивое отношение местного населения к себе, и, соответственно, также они сами не доверительно относились к местному населению.

Ну мы общались, но сначала мы также опасались потому что люди всякие, есть как и у нас и мы настороженно смотрели на них, они на нас, но есть люди, которые сами приходили к нам и благодарили, что мы там стоим, что им так безопаснее когда здесь часть. Так рассказывали, что жили в подвалах по полгода, когда их обстреливали, Лисичанск, там

16 СУА УКУ: Людмила, 1979, Львовская область, Яворовский район, с. Молошковичи, военная. 
населения есть какое хорошо к нам относилось, и которое плохо. Были такие, которые говорили, а зачем вы сюда приехали, нам нужен русский мир, а что вы здесь делаете, ну всякие. Даже на День Независимости, когда мы выезжали в город, то одни хлопали нам и махали руками, а другие кулаками, всякое было, там нельзя сказать, что 50 на 50. Была там такая соседка, что помогала и ребятам форму стирала, то там говорили, что ее обзывали всяко, что она поддерживает украинское войско. Почему она ту форму стирает и вешает на дворе, и так навешает на дворе целые шнурки, то немного опасно и всякое ${ }^{17}$.

[...] такой любительский Вертеп организовали и ездили по Бахмуте. Очень часто у нас в госпитале проводились, ввели были такие кофейные встречи. И раз в месяц, раз в месяц старались. И обсуждали там, например, выносили тему какую-то, какой-то определенной книги или определенного автора, определенной этот во. И вот люди себе там этот во [...]. Предложили им. Старались каких украинских писателей или украинских поэтов там этот. И приходили местные, там те местные активисты. Подтягивали людей. Было такое, что было 10 человек. Было такое, что было и до 50-ти человек. Как когда. Как кто мог. Но старались таким образом просто поднять немножко какой-то уровень ну, национализма, ежели можно так сказать. Поэтому, что том, что там это нужно. К детям ходили. Конечно, к детям несколько раз было такое, что ходили, там с учителями некоторыми так дружили. Так же волонтерами, которые помогали, помогают. И вот они говорят, может бы мы так организовали такой типа урок. Там-то расскажете детям, что-то. Были такие дети, например, в 11 классе было так два, в двух 11 классах. В один пришли, потом в другой пришли. И на одном, один, чувствовалась такая какая то холодность от детей. Реально такой, такая настороженность. Дети сидели и ну, не воспринимали, слушали, вообще слушали внимательно, не перебивали, не это ли во. Ну, скажем так, такая культура общения была высокая. Но чувствовалась такая отчужденность тех детей от совсем ну, то есть, ты понимал, что, что дети с совсем другого мира. И когда, например, пришли во второй класс. Тот же 11, но параллельный класс. Когда общались с теми детьми, дети и какие-то вопросы задавали, и что-то их интересовало, что-то они там, что-то может что-то то. После урока «а можно мы с вами сфотографируемся?». То есть, не принудительно, не это. Они то сами. Совсем была иная атмосфера, совсем иная. И говорим вот, какая разница, объясните нам это? Ну, это дети были, скажем так, элиты, класс, дети одного класса родителей. А это были дети более простого населения. Очень большая разница в том ощущалась. Так знаешь, энергетически ты чувствовал, что ты совсем в другом корыте. [...] И чисто так ну, как, как в конце уже встречи говорю «дети, я вам хочу такой небольшой подарок сделать. Пусть Матерь Божья вас хранит в течение вашей жизни». Я просто ну не подумала. Здесь, наверное, во Львове я бы даже не задумалась. Здесь дети бы нормально это все восприняли. Там, когда я раздала детям те образочки, те медальончики я раздала. А учительница сразу здесь же она встала и говорит «дети, кому тот образочек не нужен, я вас очень прошу, вы не выбрасывайте, вы поставьте мне на стол». Правда, с целого класса, то было первый раз я сделала это во, второй раз я уже сознательно сделала в том же втором классе. Но тот первый раз, как говорится, был уроком для меня потому, что я просто не думала, что кто-то может отказаться, понимаешь... ${ }^{18}$

17 СУА УКУ: Наталия, 1978, Львовская область, Яворовский район, с. Нагачив, военная.

18 СУА УКУ: Мирослава, 1970, Львовская область, Пустомытовский район, с. Николаев, гражданский медик. 
Pobrane z czasopisma Annales I - Philosophy and Sociology http://philosophia.annales.umcs.pl Data: 26/04/2023 15:33:54

Находясь в зоне боевых действий женщины, как правило, оказываются наедине с военной повседневностью: не слишком удобной военной формой, отсутствием общих и специальных женских средств гигиены, необходимостью совместного проживания с мужчинами, дефицитом медицинского обслуживания и т.д. Неоднозначное отношение, в первую очередь, общества к женщине на войне, на ее присутствие в боевой группе, в армии вообще - психологически травмирует женщин, которые хотят воевать. Но, те из них, которые имеют опыт пребывания в АТО, даже в таких условиях находят силы проявлять свои лучшие профессиональные качества наряду с мужчинами. На войне роли не делятся на мужские и женские. Если женщина приняла для себя решение участия в военных действиях, то она воюет наравне с мужчинами. Она адаптируется к условиям войны, физическим и психологическим нагрузкам наравне с мужчинами.

После возвращения домой респондентки жалуются на плохой сон, свое депрессивное состояние, нежелание общаться с родными, мысли о том, что никто не понимает их на мирной территории. Послевоенная психологическая реабилитация у женщин проходит иногда очень сложно. Именно интервью дает возможность женщинам участницам боевых действий улучшить свое психологическое состояние, почувствовать свою важность и нужность в обществе. Биографическое интервью или «рассказ о себе» с самоанализом и саморефлексией - это первый шаг к адаптации женщин от военных к мирным условиям жизни.

\section{БИБЛИОГРАФИЯ}

Arkhiv ustnoy zhenskoy istorii pri Lektorii Soyuza Ukrainok Ameriki Ukrainskogo katolicheskogo universiteta.

Buryak L., Zhinka v ukrayins'komu istorychnomu naratyvi: avtory, ideyi, obrazy (druha polovyna KHIKH - persha tretyna KHKH st.), Kyyiv 2010.

Cherez ATO proyshlo shist' tysyach zhinok, www.ukrinform.ua/rubric-ato/2349421-cerez-ato-vzeprojsli-sist-tisac-zinok.html [dostup: 10.10.2018].

Deychakivs'ka N., Nezvychayni doli zvychaynykh zhinok: Usna istoriya dvadtsyatoho stolittya, L'viv 2013.

Grinchenko G., Usna istoriya prymusu do pratsi: metod, konteksty, teksty, Kharkiv 2012.

Kis' O., Ukrayinky v HULAHU: vyzhyty znachyt' peremohty, L'viv 2017.

Kis' O., Zhinochyy dosvid uchasti u natsional'no-vyzvol'nykh zmahannyakh na zakhidnoukrayinskykh zemlyakh u 1940-50-kh rokakh, [w:] Skhid/Zakhid. Istoryko-kul'turolohichnyy zbirnyk, Vyp. 13-14: Istorychna pam'yat' i totalitaryzm: dosvid Tsentral'no-Skhidnoyi Yevropy, Kharkiv 2009.

Lapan T., Ukrayins'ki zhinky na prymusovykh robotakh u Tret'omu Raykhu, „Ukrayina moderna” 2007, 11. 
Nevydymyy Batal'yon (fil'm), https://uk.wikipedia.org/wiki_Невидимий_Батальйон_(фільм) [dostup: 10.10.2018].

Skokova L., Florian Znanets'kyy: avtobiohrafichnyy metod u sotsiolohiyi, „Sotsiolohiya: teoriya, metody, marketynh" 1998, nr 6.

Skokova L.H., Biohrafichni doslidzhennya v sotsiolohiyi: tradytsiya i suchasnyy dosvid, Kyyiv 2004. Sukovata V., Henderna identychnist' $i$ konstruyuvannya pam'yati kryzovykh momentiv istoriyi: zhinochi stratehiyi vyzhyvannya, ,Sotsiolohiya: teoriya, metody, marketynh” 2009, nr 2.

Suspil'ni zlamy i povorotni momenty: makropodiyi kriz' pryzmu avtobiohrafichnoyi rozpovidi, red. O.R. Kis', G. Grinchenko, T. Pastushenko, L'viv 2014.

Teper zhinky mozhut' zaymaty bil'she posad v armiyi, www.mil.gov.ua/diyalnist/genderni-pitannya-u-sferi-bezpeki/teper-zhinki-mozhut-zajmati-bilshe-posad-v-armii.html [dostup: 10.10.2018].

Zaraz v ukrayins'kiy armiyi sluzhat' blyz'ko 20 tysyach zhinok, https://ua.censor.net.ua/n435740 [dostup: 10.10.2018].

Zhinky Tsentral'noyi ta Skhidnoyi Yevropy u Druhiy svitoviy viyni: Henderna spetsyfika dosvidu v chasy ekstremal'noho nasyl'stva, red. G. Grinchenko, K. Kobchenko, O. Kis', Kyyiv 2015.

\section{SUMMARY}

In the article there are described preliminary conclusions based on the project "In Memory of Lesya Kyzyk Research Project in Oral History: Ukrainian Women in the Military Conflict in Eastern Ukraine (2014-2016)". The emphasis is on women's participation in the war in eastern Ukraine. The project was implemented as part of the study of women's oral history.

Keywords: oral history; women's history; volunteers; combat actions; post-traumatic syndrome; biographical interview

\section{STRESZCZENIE}

W artykule omówiono wstępne wnioski z projektu badawczego „In Memory of Lesya Kyzyk Research Project in Oral History: Ukrainian Women in the Military Conflict in Eastern Ukraine (2014-2016)". Uwaga koncentruje się na uczestnictwie kobiet w wojnie na wschodzie Ukrainy. Projekt został zrealizowany w ramach studiów historii mówionej kobiet.

Słowa kluczowe: historia mówiona; historia kobiet; wolontariusze; działania bojowe; zespół pourazowy; wywiad biograficzny

\section{РЕЗЮМЕ}

В статье рассмотрены предварительные выводы на основе проекта «In Memory of Lesya Kyzyk Research Project in Oral History: Ukrainian Women in the Military Conflict in Eastern Ukraine (2014-2016)». Внимание акцентировано на женском участии в войне на Востоке Украины. Проект был осуществлен в рамках женских устноисторических студий.

Ключавыя словы: устная история; женская история; добровольцы; боевые действия; посттравматический синдром; биографическое интервью 